\title{
GOVERNANCE IN THE CONTEXT OF AIR AND SPACE. LAW AND MANAGEMENT ISSUES
}

\begin{abstract}
This article refers to some very important issues such as global governance of Air and Space. There is a big trend between many experts representing different academia's, who did some research referring to global peace and security in general and in more specified areas such as environment, human rights or economy. Interesting is, that many of the researches over the global governance are still being undertaken by different scientists, so the outcomes represent many points of view, mostly international relations and politics. A lot of researches and publications touch the UN system based on the $1945 \mathrm{UN} \mathrm{Charter}^{2}$. The aim of this article is to consider if we can say about the global governance in Air and Space domain? What does this definition mean and if it is necessary to use it today? The most important question is the following: if there is a need to create a new global organization in Air and Space or those, which have been created work properly?
\end{abstract}

Keywords: global governance, international organization, aviation, outer space.

\section{INTRODUCTION}

The term "world governance" is broadly used to designate all regulations intended for organization and centralization of human societies on a global scale. The Forum for a new World Governance defines world governance simply as "collective management of the planet" 3 . Traditionally, government has been associated with "governing", or with political authority, institutions, and, ultimately, control. Governance denotes a process through which institutions coordinate and control independent social relations, and that have the ability to enforce, by force, their decisions. However, authors like J. Rosenau have also used the term "governance" to denote the regulation of interdependent relations in the absence of an overarching political authority, such as in the international system (Rosenau, 1999). Some now speak of the development of "global public policy" (Stone, 2008). „Global governance" is generally defined as an instance of governance in the absence of government. There is no government at the global level. Today's desire is to improve the functionning of global governance what has little to do with wanting to create a world government. "Global governance" or "world governance" is a movement towards political cooperation among transnational actors, aimed at negotiating responses to problems that affect more

\footnotetext{
${ }^{1}$ Małgorzata Polkowska, DSc, PhD, Associate Prof., the Faculty of Management, Rzeszów University of Technology, al. Powstańców Warszawy 12, 35-959 Rzeszów; e-mail: m.polkowska@prz. edu.pl. ORCID: 0000-0002-6633-2222.

2 UN Charter 1945, www.treaties.un.org.

${ }^{3}$ Forum for a New World Governance; Reasons for this Forum for a new World Governance.
} 
than one state or region. It is connected to the international relations, which are one of the areas of social relations. Governance can't be completely unaware of its interdependencies with the rest of the world. These interdependencies are now quite obvious and the need to take into account the interfaces that link different domains is recognised by all (Calame, ed., 2001).

They practically come between the representations of different organized social groups (from tribes, nations, classes and countries to companies, banks, unions, corporations and associations), which are entities developing mutual contacts of different nature. They are both subjects of international law and subjects of all kinds of relations: political, economic, cultural, scientific, technical, military, ideological, informational and others. International relations are distinguished from other areas of social relations that take place within individual countries by three features: greater scope, a greater range of subjects, objects and space; 2) greater complexity of conditions and mechanisms for achieving objectives, interests and values of particular entities; 3) polycentric and poliaric structure of securing maximization of interests and values of these entities in the realities of international life. In cognitive terms, "international relations" are associated with a branch of knowledge, which is a reflection of real international life, an independent scientific research discipline $(\mathrm{Ku}-$ kułka, 2000).

\section{GOVERNANCE IN AIR}

The task of international aviation law is to unify internal regulations, e.i. in the field of civil liability or technical and safety issues. International air navigation requires the use of foreign airspace. The authorization to do so may result from an international agreement (multilateral or bilateral) or from an act by an intra-entity State which exercises sovereignty over the airspace concerned (licenses or concessions) (Góralczyk, Sawicki, 2007). The Chicago Convention 1944 (ICAO Doc. 7300/8) is ICAO's fundamental was well as a multilateral air navigation treaty that regulates the relations of the Contracting States inter se. The preamble of the Convention clearly reflects the fact that the signatory States (ICAO Member States) have agreed principles and arrangements in support of the safe and orderly development of international civil aviation, which are complemented by the objective of ensuring the proper and economic functioning of international air transport services and their establishment on the basis of the principle of equal opportunities (Abeyratne, 2014).

The Chicago Convention recognized the principle of national sovereignty over its airspace and of the freedom of private civil aircraft to fly over the territory of States Parties. The final document of the air conference (concluded on 7 December 1944) consisted of the following parts: 1/ Final Act 2/ Five annexes, namely I - Interim Agreement on International Civil Aviation, II - Convention on International Civil Aviation, III - International Air Services Transit Agreement, IV - International Air Transport Agreement - Five Freedoms of the Air, V - Drafts of Technical Annexes. Documents I, II and V were signed by all delegations, document IV by 17 delegations and Document III by almost all the others. With the exception of Instrument II (Standing Convention), which was to be ratified, the other instruments were to enter into force on the date of their acceptance by the Governments of the Member States, which had been notified to the Government of the United States. Moreover, there is nothing to prevent the signatories of the Convention from granting one another the "freedoms" provided for in documents III and IV (Polkowska, 2004). 
The Convention gives the State certain rights, such as the possibility to introduce prohibited zones and temporary flight restrictions (Article 9) and to impose coercive measures on aircraft operating in violation of the rules (Article 3 bis). Each State is also entitled under the Convention to lay down rules on the movement of aircraft within its territory (Article 11), on air traffic (Article 12) and on arriving passengers and cargo (Article 13). The State designates airports and lays down the conditions for their use (Articles $10^{4}, 15$ and 68). The State is also entitled to inspect foreign aircraft (Article 16). The Chicago Convention imposes a number of obligations on States Parties. These include, inter alia, compliance with the rules for registration of aircraft in one country with transferability (Article 18), ensuring that the aircraft registered therein bear the appropriate nationality and registration marks (Article 20), are properly equipped and have documentary evidence (Articles 29 to 36). In addition, each State exercises the control functions assigned to it over an aircraft. When an aircraft is registered in one State and the operator is established in another, both States are responsible for the unlawful use of the aircraft (Article 3 bis). Other tasks of the Convention include facilitating and improving the navigation and handling of aircraft, crew, passengers and cargo (Article 22), issuing customs and immigration regulations in accordance with the rules of the Convention (Article 23), assisting aircraft in distress, investigating the circumstances of foreign aircraft accidents, allowing the State of registry to send observers and subsequently sending reports and the results of investigations to that State (Article 26). The Convention considers it very important to cooperate in ensuring the uniformity of national legislation in accordance with ICAO standards and recommendations on the safety, regularity and efficiency of air navigation (Article 37).

The Convention on International Civil Aviation, signed in Chicago on December 7, 1944, entered into force on April 4, 1947 (ICAO Doc. 7300/8). This Convention refers to, and in some cases even copies, the provisions of the Paris Convention of 1919 (Freer, 1986). The preamble to the Chicago Convention refers to the development of international civil aviation, which can make a significant contribution to creating and maintaining friendship and understanding between the peoples of the world. The preamble is supplemented by a provision stating that the governments of the States signatory to the Convention will strive to reach an agreement so that international civil aviation can develop properly and, above all, in compliance with the principles of safety.

The text of the Convention was divided into 4 parts: Part I - Air Navigation, Part II International Civil Aviation Organisation, Part III - International Air Transport, Part IV -

\footnotetext{
${ }^{4}$ (Larsen, 2015); ICAO has not managed to reach agreement on an international treaty that would make providers liable for faulty GNSS. Anex 10 to the Chicago Convention is the document establishing GNSS air navigation standards. ICAO adopted Assembly Resolution A32-19 in 1998 to the effect that States shall seek to secure the highest practicable degree of uniformity in the provision and operation of GNSS Services. ICAO has therefore worked extensively on coordination of the GNSS services of the various national providers. ICAO has been able to get GNSS providers agreement to create a seamless interoperable web so that pilots do not need to be concerned about shifting from one GNSS system to another. Author thinks that art 37 of the Chicago Convention gives ICAO function of establishing uniform international standards and recommended practices and procedures. A similar central regime for GNSS could establish uniform operating international standards for GNSS. Under this model standards and recommended practices and procedures for GNSS would be established centrally. The existing regulatory framework for GNSS is weak; in the long run, a much stronger international coordination structure, more like ICAO is needed- one that establish and enforce uniform standard for GNSS.
} 
Final Provisions, with 22 chapters and 96 articles in all (the Paris Convention had only 43 articles). Each article of the Chicago Convention is preceded by an additional title. The official languages of the Chicago Convention were English, French and Spanish (the Paris Convention is drawn up in French, English and Italian). Subsequently, the text of the Convention was also drafted in the Russian, Arabic and Chinese languages (Dempsey, 2015) . Today ICAO uses 6 official languages (English, French, Spanish, Chinese, Arab and Russian).

\section{GENERAL PRINCIPLES AND APPLICATION OF THE CONVENTION}

Chapter I contains provisions on issues such as sovereignty, territory, aircraft and abuse of civil aviation. Article 1 of the Convention gives States complete and exclusive sovereignty over their territory over the airspace. Every State has the right to determine international traffic rights for commercial flights, including the granting or refusal of rights to operate scheduled services to foreign carriers. This text, although commonly attributed to the authors of the Chicago Convention, has been moved here from the Paris Convention (Article 1, first paragraph). It is the Paris Convention, for the first time in the history of aviation law, which has used the term sovereignty. The condition is that this sovereignty is complete and exclusive. It is up to the state to decide who will use its airspace and under what conditions. A State may freely dispose of its airspace, prohibit, prescribe or permit flights, and take all measures provided they are not prohibited by international law. The provision of its own airspace depends only on the will of the country concerned. The conditions of use of this area shall be governed by the national legal order and by international agreements to which the State is a party. As far as foreign civil aviation is concerned, it must operate in accordance with the rules laid down by the national law of the State concerned. This principle has therefore become a cornerstone of air law, breaking with the principle of the Common Aviation Area as a heritage of humanity and the so-called principle of open skies that has prevailed for centuries. Such a provision was proposed back in 1910 at a diplomatic conference in Paris (Żylicz, 1963).

Article 1 refers to the complete and absolute sovereignty of each State over its airspace. This provision does not define the term "airspace", therefore according to some authors it causes misunderstanding and ambiguity in national legislation (Abdurrasyid, 1989). Everyone's word means that the Convention speaks here in the interests of all states, including those that are not parties to the Convention (as in the Paris Convention of 1919) (Jennings, 1945) . Many air law theorists will later point out that this is more about freedom of air navigation than about freedom of air itself. There has also been no agreement, and until now there has been no limit to airspace. It can also be a question of whether absolute sovereignty also applied to space at that time, or whether it concerned only absolute, that is, unlimited powers of the state. Article 1 was shaped by the British and Canadian proposals. The US proposal was too narrow (each contracting state) and solutions from the Paris and Hawaiian Conventions were adopted (Coob, 1965; Polkowska, 2011)

The US confirmed the "nationality requirement" in the certification process and reserved cabotage rights for its carriers through the Air Commerce Act of 1926. The US soon

\footnotetext{
${ }^{5}$ Furthemore all formal business at ICAO is conducted in six official languages requiring large teams of translators and imposing relativeley enormous operational costs. English is a global language of aviation.
} 
raised the national control requirement to $75 \%$ through the Civil Aeronautics Act of 1938, but some recognize that despite a number of provisions of the Convention (Articles 1, $6^{6}$, $17,18,31-32$ ) defining State sovereignty over its airspace, the Chicago Convention does not contain a provision on the nationality of the carrier. These provisions started to appear soon in bilateral agreements. These restrictions are considered by some to be detrimental to the development of international civil aviation; indeed, they do not exist in other areas of the economy (e.g. telecommunications, television, banking and even atomization) (van Fenema, 2007). There are also reasons for leaving the nationality rules in the hands of the carrier. These include in particular the protection of national safety, ensuring that the exchange of traffic rights and other rights is used by the carriers of the State which has negotiated the agreement, the protection of national carriers from excessive competition and the avoidance of flags of convenience which do not respect safety and environmental rules (Dempsey, 2007).

Article 2 sets out a territorial limit (land areas and adjacent territorial waters), using the term sovereignty. The text of this Article is broader than that of the corresponding provision in the Paris Convention and favors the signatories to the Convention on larger territories. The geographical scope of the Convention is extended in Article 2 to include the territories of colonies, protectorates and other dependent countries. However, there is no explanation as to whether an area or part of a territory, after its independence, is a signatory to the Chicago Convention. The majority of authors consider that a new state does not automatically become a party to the Convention; it must deposit its authentic instruments with the US depositary pursuant to Article 92 (Abeyratne, 2005).

\section{TASKS AND STRUCTURE OF THE INTERNATIONAL CIVIL AVIATION ORGANISATION}

ICAO is a specialized United Nations agency established by States in 1944 for the purpose of administering the administration and management of the Chicago Convention.

The vision of ICAO is to achieve sustainable growth in the global civil aviation system. The mission is acting as the Global Forum of States for International Civil Aviation. ICAO develops policies and standards, conducts compliance audits such as $\mathrm{USOAP}^{7}$ and $\mathrm{USAP}^{8}$ dealing with last emerging threats to civil aviation- cybersecurity, conducts investigations and analyses, assists and builds air transport capacity through many other activities and through the cooperation of Member States and stakeholders. ICAO's strategic objectives as part of its current mission to support and enable a global air transport network that meets or exceeds social and economic development and the connectivity needs of global companies and passengers, and recognizes the clear need to anticipate and manage the projected doubling of global air transport capacity by 2030 without unduly compromising the safety, efficiency, comfort and environmental performance of the system, ICAO has established five

\footnotetext{
${ }^{6}$ (Abeyratne, 2013) The final consideration is whether the Chicago Convention is adequate fort he current aviation scene. The Chicago Convention cannot be superseded by a brand new instrument as many od its provisions are still relevant and useful. Hovewer one article at least should be changed- art. 6 saying about permission or authorisation given ton o scheduled international air service. 7 Universal Safety Oversight Audit Programme - Continuous Monitoring Approach (USOAP CMA).

${ }^{8}$ Universal Security Audit Programme (USAP).
} 
comprehensive strategic objectives: safety (improving global civil aviation safety ${ }^{9}$; this strategic objective focuses primarily on the state's regulatory oversight capacity. The Global Aviation Safety Plan (GASP) sets out the main actions for three years), efficiency and effectiveness of air navigation (increasing the capacity and efficiency of the global civil aviation system), strengthening global civil aviation security and facilitation, economic development of air transport (promoting the development of a robust and economically viable civil aviation system and environmental protection (minimizing the environmental impact of civil aviation activities) (www.icao.org).

ICAO is working with 192 Member States and industry groups to reach a consensus on international standards and recommended practices in the field of civil aviation and on a policy to promote a safe, efficient, safe, secure, economically sustainable and environmentally responsible civil aviation sector.

These SARP's and policies are used by ICAO Member States to ensure that their local civil aviation operations and regulations are compliant with global standards, which in turn allow the safe and reliable operation of more than 100000 flights per day on the global aviation network in each region of the world.

In addition to its core work of consensus building in international SARP's and Member States' and industry's policies, and among many other priorities and programmes, ICAO also coordinates States' assistance and capacity building to support numerous aviation development objectives; develops global plans to coordinate multilateral strategic developments in the field of safety and air navigation; monitors and reports on a number of performance indicators for the air transport sector; and monitors Member States' civil aviation safety and security oversight capabilities. ICAO shall provide the global aviation community with a comprehensive overview of the annual programmes, activities and achievements of the Organization. These actions are being implemented in support of ICAO's strategic objectives and tasks as defined in the Chicago Convention.

\section{ICAO AS GLOBAL GOVERNANCE}

Particular importance is creating ICAO and its general nature. ICAO (and temporarily PICAO earlier) is fully authorized to adopt any necessary international standards for worldwide unification of the technical and safety procedure so vital to every phase of international air navigation. No further world organization is needed to meet these problems. In the economic and political fields the need for international organization remains unsatisfied. The Convention has given ICAO very limited economic powers, and these are largely of an administrative and advisory character, such as research; study of operation of international

9 The ICAO Runway Safety Programme coordinates global efforts to improve the safety of the runway in cooperation with partner organizations, including partner organizations: International Airport Council (ACI); Organisation of Civil Aviation Services (CANSO); European Aviation Safety Agency (EASA); EUROCONTROL; United States Federal Aviation Administration (FAA); Aviation Safety Foundation (FSF); International Air Transport Association (IATA); International Business Aviation Council (IBAC); International Coordination Council of Aviation Industry Associations (ICCAIA); International Council of Aircraft Owners and Pilot Associations (IAOPA); International Federation of Airline Pilot Associations (IFALPA); International Federation of Air Traffic Controllers' Associations (IFATCA). The programme shall support the establishment of multidisciplinary runway safety teams (RSTs) at airports, which shall involve the joint efforts of regulatory bodies, air traffic management authorities, airport operations and aircraft operators. 
air transport, including ownership of international services on main routes; investigation of situations appearing to present avoidable obstacles to development of air navigation; collection and publication of information, including cost of international operations and subsidies from public funds. Under certain circumstances ICAO may provide and administer airports and facilities required by international air services. But ICAO has no power to fix or control rates, allocate routes, or control operating frequencies or capacity (Cooper, 1968).

The two main characteristics of ICAO are: that is created by states (the ICAO bends to the will of its membership. It has the ability to influence, but it cannot force any member to act against its national interest) (Mackenzie, 2010), more specifically, as states themselves are abstractions, by duly authorized representatives of States; and they are created by treaty, which is a written agreement signed by the states parties to it and governed by international law. States can only act by and through their agents. Different government departments of instrumentalities of states bear responsibility for different international organizations. In the case of ICAO the most likely government department that would be responsible for the Organization within a state would be ministry or departments of transport or aviation as the case may be. The third characteristics that distinguishes an international organization as a "club" of States without just being the spokesperson or mouthpiece of those states is that it is expected to have a will of its own. ICAO's independent will recognized by the Government of Canada for purpose of its activities within the country is closed in a provision that ICAO has an identity of its own capable of entering into contracts. ICAO is by no means sovereign in its own rights, although courts have on occasion referred to sovereign rights of an organization merely to seek a compromise between absolute acceptance or parity between a State and an organization and absolute refusal of an international organization's ability to perform acta jure imperii (governmental acts) (Abeyratne, 2012).

Within the reality, however, the organization has considerable ability and a degree of independence tu pursue its goals. It has the authority to settle disputes between members, at least in some circumstances, and through ist Legal Committee it has been in the vanguard of the establisment of international air law. Both fields, in their own separate ways, deal with solving problems facing the orderly development of international civil aviation (Mackenzie, 2010).

The most simplistic definition of "governance" which may refer to the air domain would be that it is the process of decision-making and the process by which decisions are implemented (or not implemented as the case may be). Governance can be categorized into several institutional bases and used in several contexts such as corporate governance (Jacquet, Pisani-Ferry, Tubiana, 2002), international governance, national governance and local governance. Good governance must be rewarded. Recognition should be given through "satisfaction surveys" where a direct causal nexus could be drawn between the manners in which the worker was enabled to reach a level of satisfaction with governance provided. Positive changes in expectation and results obtained should be weighed against perceived adequacies of the business entity in the provision of services.

Trust in employer, through increased levels of health and well-being (which must necessarily include a sense of security of life, habitation and movement) both from cultural and religious perspectives should be a primary indicator. The elimination of corruption is a key to good governance and civil society, which has been overwhelmingly proactive in building awareness on human right issues, has succeeded in persuading the international community of the value for transparency and honesty in public transactions. Arguably, the most important key to good governance is benevolence and understanding. A good 
employer must assure its workforce that it has their well-being at heart and pro-actively move towards achieving that goal.(Abeyratne, 2012).

It may be said that ICAO was simply a technical organization outside the realm of international policies. The rise of international terrorism, armed attacks and sabotage, and the interception of civil aircraft brought the outside world into the halls of ICAO and there was no way to escape it. ICAO provided an ideal international stage where antagonists could face each other and international aviation disputes could unfold through political debates, investigate teams and reports amd public condemnation. In search for solutions to international aviation terrorism, ICAO emerged as the prime vehicle for the establishment of international air law and the regulations for ensuring aviation security. ICAO embrace the task and its role in aviation security is probably the single most distinguishable feature of its public profile today. ICAO's biggest challenge is to motivate governments to come to agreement on terms, ratify its conventions, implement ist standards and take concerted action against terrorism. In pursuing this goal of safety in aviation, ICAO has acted as part legal and technical think- tank and reserach institute, part information collection agency, part international public forum and debating club, part foreign aid service an das a global regulator, monitor, reference and support group all roled into one.

The main connotations of safety obligations include the duty to provide safety oversight, the duty to refrain from the use of weapons against civil aircraft in flight and the duty to punish certain criminal acts endangering the safety od civil aviation.

Safety obligations are laid down not for the interest of an individual State, but for a higher purpose: the safe and orderly development of international civil aviation. Traditionally ICAO focused on development and adoption of treaties, standards and recommended practices and other provisions relating to aviation safety, leaving their implementation basically in the hands of its Member States. Since 1990's there has been a paradigm shift from this pattern with the landmark decision to launch the USOAP (Universal Safety Oversight Audit Programme). This initiative was followed by the USAP (Universal Security Audit Programme). The results oft he audits demonstrate not only the need to adopt safety regulations but also the more pressing need to enforce and implemnt them (Huang, 2009).

The 1990's was a decade of resurgence for the ICAO. When the decade began the Organization faced serious challenges from a number of sources, with other groups, organizations and states and regional groupings intruding into area that ICAO had always believed were its own. By the end of the decade it had largely reasserted its role in international civil aviation. ICAO had reassumed a leadership role as the machinery through which the discussion of the economic regulation of international civil aviation would unfold; in aviation safety it had responded to the challenges from the Americans and the Europeans with the introduction of ICAO's safety oversigh program; and it had taken the initiative from IATA to amend the Warsaw Convention on aviation liability (1929) (https://www.mcgill. ca/iasl/files/iasl/warsaw1929.pdf ). In this process, the accomplishments had produced a greater and more ditrect role for ICAO in the oversight and implementation of its conventions and standards. In the Montreal Convention and Convention on Plastic Explosives (1991) (https://www.un.org/ruleoflaw/files/3dd90f0c7.pdf), ICAO, maintained continous involvment in their revision; and with resoect to the latter convention it was a role that ICAO assumed not only for commercial aviation but for the international community as a whole. ICAO ended the decade in a more stable and influential position in the international system (Mackenzie, 2010). 
ICAO also had a large group oft talented individuals- from aviation specialists and technicians to leaders such as Assad Kotaite (Kotaite, 2013) ${ }^{10}$ and others- who provided the skills, knowledge and diplomacy necessary for ICAO to function successfully in the international arena while also maintaining focus on ist prime goal of enhancing aviation safety. The modern era had transformed ICAO and brought it an unprecedented degree of public attention in the latter part of the twentieth century. The Cold War may have faded away but this transfomation for ICAO was permanent (Mackenzie, 2010).

\section{GLOBAL GOVERNANCE REGIME FOR SPACE}

After launching the Soviet Sputnik into Space in 1957, it became apparent that the principle of state sovereignty over the air space above its territory could not be upheld in relation to space exploration. It was noted that it would be very difficult for individual countries to agree to fly satellites and other devices in orbit more than 100 miles above the Earth's surface. As a result, two new concepts of national air sovereignty emerged after 1957. According to the first, it was considered that, at the height of the trajectory of a spacecraft's, this space was no longer subject to national sovereignty. This would mean that the sovereignty of states over their airspace would be limited to a certain amount, to which it borders with space. However, it is difficult to say where this limit is. (Shaw, 2000). The development of space law was accelerated in 1958, when the UN General Assembly established the Committee on Peaceful Uses of Outer Space- COPUOS. This committee has set up two subcommittees, one legal and the other scientific and technical (Hermida, 2004). This was a turning point for international cooperation in space and for the development of international space law. Another significant step in the development of space law was taken in 1963, when the General Assembly adopted the Declaration of Principles Governing the Exploration and Use of the Space. This resolution laid the foundations for the 1967 Space Agreement. COPUOS then created four other international treaties that regulate human activity in space. In addition, a series of legal principles have been developed for the use of space (including direct satellite broadcasting, remote sensing and nuclear weapons) (Jasentuliyana, 1997).

Since the beginning of the Space Age, international cooperation in the peaceful uses of outer space has evolved in such a way as to provide the impetus for a consideration of international mechanisms and infrastructures for space cooperation and coordination mechanisms at the national, international, regional and interregional levels.

The governance of space, which has been described as humanity's most expansive global commons, has become increasingly complex owing to the growing number of both governmental and non-governmental actors, and to the emergence of new technologies and approaches such as public-private partnerships and private funding initiatives.

Although not yet defined at the intergovernmental level, the concept of global space governance could be interpreted as referring to international actions to or the manner (process) of, governing and regulating space-related activities. As such, it encompasses a wide range of instruments, institutions and mechanisms including international and regional treaties, agreements and regulations, model national laws and regulations, as well as a wide

10 A. Kotaite (1924-2014) was a former Secretary-General and Council President of the International Civil Aviation Organization from 1976 to 2006; after retirement, he was named President Emeritus of the ICAO, he was awarded many times for his achievements in mainaning the peaceful and safe development of Aviation; in September 2013, he received the highest honour in the world of civil aviation, the Edward Warner Award. 
range of international cooperative mechanisms utilized in space cooperation, guidelines and transparency and confidence-building measures, all of which are aimed at ensuring a certain level of predictability and orderly conduct of space activities.

In COPUOS, the term "global space governance" refers primarily to the institutional framework for the governance of international cooperation in using outer space for peaceful purposes. That framework includes the United Nations treaties and principles on outer space, the relevant guidelines adopted by the Committee and the resolutions on outer space adopted by the General Assembly, as well as supporting efforts undertaken at the national, regional and global levels, including by entities of the United Nations system and international space-related entities. To increase coherence and synergy in international cooperation in space activities at all levels, international initiatives exist for cooperation on specific aspects of the exploration and use of outer space, such as Earth observation and global navigation. Furthermore, multilateral coordination mechanisms are in place through which space-system operators coordinate the development of space-system applications for the benefit of the environment, human security and welfare. Those, too, form an integral part of global space governance ${ }^{11}$. The role of international space organizations is crucial for the political, economic and social environment in which space activities and policies are conducted. There are different classifications of organizations: according to their scope of activities (e.g. national, regional, global), the nature of their ownership and governance (e.g. governmental, mixed and non-governmental), and their functions (e.g. scientific, operational and similar). It should be noted that the number and role of non-governmental organizations, including research institutes, laboratories and other non-profit entities (foundations and the like) is currently increasing. They shall provide expertise and opinions to intergovernmental organizations. These may be scientific or market organizations, supporting space policy making bodies. They all organize conferences and thematic seminars, working groups (for example on space tourism) and cross-border long-term space programs (Edda, 2011).

The legitimacy of international organizations, especially the UN, is significant. Sometimes their activities are criticized as ineffective and not adapted to the contemporary challenges (this applies especially to larger organizations). It is even proposed to replace the existing organizations by a single global space organization. However, it must be borne in mind that it is the States themselves who are members of the organization and it is for their sovereign decision whether or not they wish to join. It is also up to states to decide whether they want to be bound by international treaties and fulfil their obligations. Due to the lack of space, some of the most important organizations are listed below.

\subsection{Committee on the Peaceful Uses of Space (COPUOS)}

The United Nations has been involved in space activities ever since the very beginning of the space age. Ever since the first human-made satellite orbited the Earth in 1957, the UN has been committed to space being used for peaceful purposes. This launch, as part of International Geophysical Year, marked the dawn of the space age, the first use of satellite technology for the advancement of science, and the beginning of human efforts to ensure the peaceful uses of outer space. This was followed in the 1960's by a rapid expansion in

\footnotetext{
11 A/AC.105/1137, 20 September 2016 Fiftieth anniversary of the United Nations Conference on the Exploration and Peaceful Uses of Outer Space: the Committee on the Peaceful Uses of Outer Space and global governance of outer space activities V.16-05982 (E), p. 2.
} 
the exploration of space, starting in April 1961 when Yuri Gagarin became the first human being to orbit the Earth, and culminating in Neil Armstrong's "giant leap for mankind", in July 1969. In the midst of the Cold War, there was a growing concern in the international community that space might become yet another field for intense rivalries between the superpowers or would be left for exploitation by a limited number of countries with the necessary resources (http://www.unoosa.org/oosa/en/ourwork/copuos/history.html). As already mentioned, the United Nations (UN) plays a leading role in the development of space law. In December 1958, the UN General Assembly established the COPUOS Committee, a body made up of eighteen members. A year later, the Assembly granted it the status of a permanent body and confirmed its mandate. From a jury point of view, COPUOS has become a qualified support body (Art. 57 of the UN Charter; http://www.un.org/en/charterunited-nations/). Initially, COPUOS was intended to be a political organization with the aim of strengthening international cooperation between space-faring nations and not (as is the case today) a technical organization with the competence to carry out direct operational activities.

In 1959, the General Assembly established COPUOS as a permanent body, which had 24 members at the time, and reaffirmed its mandate in resolution 1472 (XIV) - "International Co-operation in the Peaceful Uses of Outer Space Since" (http://www.unoosa. org/oosa/oosadoc/data/resolutions/1959/general_assembly_14th_session/res_1472_xiv.

html) then, COPUOS has been serving as a focal point for international cooperation in the peaceful exploration and use of outer space, maintaining close contacts with governmental and non-governmental organizations concerned with outer space activities, providing for exchange of information relating to outer space activities and assisting in the study of measures for the promotion of international cooperation in those activities.

The work of COPUOS has been assisted by the two subcommittees: Scientific and Technical Subcommittees (hereinafter STS) and Legal Subcommittee (hereinafter LSC) (Thaker, 1997). Each subcommittee shall be composed of representatives of the same countries. The complex issues which have arisen alongside the development of space technology are the main concern of the two COPUOS Subcommittees, which met for the first time in Geneva in 1962 and then regularly each year.

Members of COPUOS are States and since 1959 the membership of COPUOS has grown continuously, making COPUOS one of the largest Committees in the United Nations. In addition to States a number of international organizations, including both intergovernmental and non-governmental organizations, have observer status with COPUOS and its Subcommittees. The Committee currently comprises seventy countries, representing about one third of all UN members. In 1961, the General Assembly demanded that the Committee maintain close cooperation with governmental and non-governmental organizations dealing with space issues, and mainly promote international cooperation for the peaceful use and exploration of space. UNOOSA provides the Secretariat services to COPUOS and its two Subcommittees, which continue to serve as a unique platform for maintaining outer space for peaceful purposes at the international level.

The LSC has made a major contribution to the development of international space law (it has succeeded in adopting a number of documents, including five space treaties). Currently, COPUOS and the two subcommittees meet every year in Vienna in bi-weekly sessions to consider the problems proposed by the General Assembly, the reports that are being issued and the issues that have been raised by Member States. Draft documents, including treaties, declarations and resolutions, shall be adopted without a vote by COPUOS and its 
subcommittees and submitted to the General Assembly, which is competent to deal with space and space activities, for approval. It meets in annual (ordinary) sessions, adopts resolutions on international cooperation for the peaceful development of outer space, provides guidance for the work of COPUOS and adopts decisions.

The legislative process is very detailed and time-consuming, with many informal discussions and consultations. The first step in the legislative process is to discuss the proposed text at the annual meeting of the LSC (Jankowitsch, 2007). The draft shall then be submitted to the General Assembly of the United Nations. The inter-sessional period shall be used for the consultation of States. Once the text has been finalized by COPUOS, it is sent to the UN General Assembly, which adopts a resolution containing the agreed text and recommends that States adopt it. Some point out that it is fair and takes into account the voices of developing countries (Ferrier, 1995). Others say that the quality and qualifications of the national representatives on the committee are mediocre. This may be one of the reasons for delays in the lawmaking process. One of the Committee's working principles is the principle of consensus, which requires numerous consultations and discussions and takes time in the process.

Although the most important principles - on arms, security and freedom of exploration - have been adopted in the five space treaties, it is hard not to agree that modern technologies have not been included in these treaties, so changes and updates are needed (Barnet, 2003). On the issue of remote sensing, for example, the Committee has tried for thirteen years to find a compromise between rich and poor countries (Jasentuliyana, 1997). Some authors say that 1979 marked the end of international space legislation. Many of them stress the importance of the existing space conventions, but on the other hand recognize that they are outdated and insufficient. The review of existing space treaties should be carried out by technicians, financiers, lawyers and scientists alike, as well as by those involved in day-today space operations (Ospina, 2000).

\subsection{Office for Outer Space Affairs - UNOOSA}

The United Nations Office for Outer Space Affairs (hereinafter: UNOOSA) was originally established as a small expert unit within the UN Secretariat to provide services to the COPUOS Interim Committee established by the General Assembly by Resolution 1348 (XIII) in 1958 (Question of the Peaceful Use of Outer Space [http://www.unoosa. org/oosa/oosadoc/data/resolutions/1958/general_assembly_13th_session/res_1348_xiii.

html]). The office was initially set up as an experimental small unit within the UN Secretariat to provide services to the Committee UNCOPUOS (Committee on the Peaceful Uses of Space) set up by the General Assembly by the Resolution 1348 (XIII) from 1958. Initially, the Office operated within the UN Department of Political and Security Council Affairs. In 1968 it was replaced by in the Space Unit. In 1992 this unit was transformed into the Office for Space Affairs in the United Nations Department of Foreign Affairs, and has become transferred to the UN Delegation in Vienna.

UNOOSA is responsible for promoting international cooperation in the peaceful uses of outer space. The office serves as the secretariat for the General Assembly's only committee dealing exclusively with international cooperation in the peaceful uses of outer space (COPUOS). UNOOSA implements the Secretary-General's responsibilities under international space law and maintains the United Nations Register of Objects Launched into Outer Space. Through the United Nations Programme on Space Applications, UNOOSA conducts international workshops, training courses and pilot projects on topics that include remote 
sensing, satellite navigation, satellite meteorology, tele-education and basic space sciences for the benefit of developing nations. It also maintains a 24-hour hotline as the United Nations focal point for satellite imagery requests during disasters and manages the United Nations Platform for Space-based Information for Disaster Management and Emergency Response (UN-SPIDER) established in 2006 under UNOOSA. UN-SPIDER develops solutions to address the limited access developing countries have to specialized technologies that can be essential in the management of disasters and the reducing of disaster risks. UN-SPIDER aims at improving actions to reduce those risks or support disaster response operations through knowledge sharing and the strengthening of institutions in the use of space technologies. It also facilitates cooperation between satellite data and information providers and the different groups of users of such data, such as policymakers, disaster risk managers or emergency responders. The objective is a better flow of information on disaster risks or disaster impacts between all stakeholders and affected populations (http://www. unoosa.org/oosa/en/ourwork/un-spider/index.html).

UNOOSA together with space agencies, organize seminars and conferences. Earth observation is very important from the point of view of climate change (lands and oceans, polar areas, glaciers). Hence UNOOSA cooperates with the UNFCCC (UN Framework Convention on Climate Change). The programs that the office currently deals with are this: UNISPACE III+5, relying on innovation the approach to the implementation of the recommendations of large international conferences (states take action and coordinate it voluntarily in specific areas). UNOOSA makes recommendations for facilities located nearest to the Earth and, if necessary, for Space Mission Planning Advisory Group (SMPAG) and warns against the asteroids (International Asteroid Warning Network - IAWN) (http://www. unoosa.org). UNOOSA on a daily basis works closely with UNCOPUOS.

Moreover, UNOOSA is the current secretariat of the International Committee on Global Navigation Satellite Systems (ICG). The office also prepares and distributes reports, studies and publications on various fields of space science and technology applications and international space law. Documents and reports are available in all official languages of the United Nations through this website.

One of the most important tasks of UNOOSA is implementation of the General Assembly and COPUOS decisions. In addition, the Office supports intergovernmental discussions at COPUOS and its subcommittees and assists developing countries in the use of space technology. Issues related to the militarization of space are shared with the Geneva-based Disarmament Conference ${ }^{12}$.

In addition, UNOOSA follows the legal, scientific and technical developments related to space activities and provides advice and information to Member States, international organizations and other United Nations offices. The Office is headed by a Director and consists of two sections: the Space Applications Section (SAS), which organizes and carries out the United Nations Programme on Space Applications and the Committee, Policy and Legal Affairs Section (CPLA), which provides substantive secretariat services to the Committee, its two subcommittees and its working groups. This Committee also prepares and distributes reports and publications on international space activities and on international

12 The Conference for the Reduction and Limitation of Armaments of 1932-1934 (so- called World Disarmament Conference or Geneva Disarmament Conference) was an effort by member states of the League of Nations, together with the U.S., to actualize the ideology of disarmament. It took place in Geneva, ostensibly between 1930 and 1934, but more correctly until May 1937. 
space law. CPLA also provides substantive secretariat services to the Working Group of the Whole of the Special Political and Decolonization Committee (Fourth Committee) of the General Assembly when it considers the item on international cooperation in the peaceful uses of outer space. As UNOOSA leads UN-Space (the Inter-Agency Meeting on Outer Space Activities ${ }^{13}$, CPLA convenes and services the sessions of UN-Space. Comprising staff with legal, policy and economics background, the CPLA team works closely with UN Member States in supporting their capacity building efforts in space activities and in building national space infrastructure, by organizing workshops on space law and policy, as well as on organizational questions relating to international cooperation in space activities and on United Nations space-related activities. CPLA also works with other actors, such as regional organizations and mechanisms, in support of their efforts and cooperation in space activities

\section{CONCLUSION}

This article has shown that the global governance is created by the States. The global governance (law, management and policy) may concern every single area. The art of governance is an art of action and execution. Global governance leads to the creation of different institutions- global in nature (such as UN). The global institutions are needed today. Their initiators are the States themselves. The criticism of international institutions relates to the way in which global governance in practice is implemented by governments and institutions (international organizations). It seems that the UN system referring to the Air and Space is a good example of cooperation of states in good spirit. Seemingly it's strictly connected to the technical issues, in which safety and security are priorities for all. There are a lot of entities (ex. institutions) working together. On the other side there was and will be some political influence in those two domains. It may be seen in the elections of the organs, political structure and influence of the powerful states in Aviation or Space.

The Air and Space domain develop very rapidly. The increasing number and variety of players in Air and Space domain, each of which has its own priorities, perspectives, and goals for the structure of the global governance system for Air and Space, complicates the development or revision of frameworks. It seems that there is no need to create a new organization or institution. There is ongoing debate among governments and nongovernmental entities regarding how to build or restructure the global system to address expanding Air and Space activities. There are questions to raise, including, who should be involved in these discussions and to what extent, as well as whether the continued use of forums such as the United Nations is the most efficient way to achieve the desired changes. It seems that States should use the experience of ICAO and UNOOSA in performing the global governance in Air and Space in transparent and trustful manner for the benefit to all mankind today and in the future.

\footnotetext{
13 The United Nations and its specialized agencies conduct a coordinated programme of activities utilizing these technologies. UN-Space, an inter-agency mechanism for such coordination, convenes annual sessions of the Inter-Agency Meeting on Outer Space Activities to discuss current and future activities, emergent technologies of interest and other related matters among UN system entities. For broader stakeholders' consultations, UN-Space organizes informal sessions open to Member States, private sector, non-governmental institutions and academia.
} 


\section{REFERENCES}

Abdurrasyid, P. (1989). State's sovereignty in airspace [in:] Liber Amicorum honouring en hommage à N.M. Matte, Paris.

Abeyratne, R.R.I. (2005). The e-passport and the public key directory-consequences for ICAO. ASL, No. 4-5.

- (2012). Air Navigation Law. Springer.

- (2014). Convention on International Civil Aviation (a commentary). Springer.

- (2012). Aeronomics and Law. Fixing anomalies, Springer.

Barnet, T. (2003). Legal fictions in the five United Nations space treaties stifle commerce and entourage a dangerous and chaotic space environment, AASL, Vol. XXVIII.

Calame, P., ed. (2001). Redefining Global Governance to Meet the Challenges of the 21st Century, Paris, October.

Cooper Coob, J. (1965). The Chicago Convention after 20 years. "Zeitschrift für Luftrecht und Weltraum-Rechtsfragen" No. 4.

— (1968). Explorations in aerospace law, selected essays by J.J. Cooper 1946-1966, edited by I. Vlasic, Montreal 1968.

Dempsey, P.S. (2007). Capital and market access in international aviation: nationality requirements and cabotage - presentation from the Macau conference (16-21 April).

- (2015), The future of International Air Law in the 21st Century, ZLW, 2 2015, $64 \mathrm{~J}, \mathrm{H} 2$.

Edda, J.A. (2011). Non-governmental Space Organizations [in:] Sadeh, E., ed., The Politics of Space: A Survey 2011266. The Politics of Space: a Survey. London and New York, NY: Routledge.

Ferrier, J. (1995). The development of International Space Law International cooperation in outer space-meeting the needs of the developing countries. Typescript at the McGill University Montreal.

Freer, D.W. (1986). A Convention is signed and ICAN is born 1919-1926. "ICAO Bulletin" No. 7, July, Special series, archives.

Góralczyk, W., Sawicki, S. (2007). Prawo międzynarodowe publiczne w zarysie. Warszawa.

Hermida, J. (2004). Legal basis for a national space legislation, Dordrecht, Boston.

Huang, J. (2009). Aviation safety through the Rule of Law. ICAO's Mechanisms and Practices. Leiden.

Jacquet, P., Pisani-Ferry, J., Tubiana, L. (2002), Gouvernance mondiale, La Documentation française, Les Rapports du CAE (Conseil d'analyse économique), No. 37.

Jankowitsch, P. (2007). The role of the United Nations in outer space law development: past achievements and new challenges [in:] Jakhu, R.S., ed., Space law-general principles. Vol. I. Montreal.

Jasentuliyana, N. (1997), Space law: the newest branch of international law. "Annals of Air and Space Law” Vol. XXII, No. 1.

- (1997), The lawmaking process in the United Nations, space law development and scope [in:] Space law: the newest branch of international law. "Annals of Air and Space Law" Vol. XXII, No. 1.

Jennings, R.Y. (1945). International civil aviation and the law, British Year Book of International Law. 
Kotaite, A. (2013). My memoirs, 50 years of International Diplomacy and Conciliation in Aviation, ICAO.

Kukułka, J. (2000). Teoria stosunków międzynarodowych. Warszawa.

Larsen, P.B. (2015). International Regulation of Global Navigation satellite Systems. JALC, Vol. 80, No. 2.

Mackenzie, D. (2010). ICAO. A History of the International Civil Aviation Organisation. Toronto.

Ospina, S. (2000). International Satellite Telecommunications: regulation by states or private parties? "Air and Space Law" Vol. XXX, No. 6.

Polkowska, M. (2004). Konferencja w Chicago i powstanie nowej konwencji o międzynarodowym lotnictwie cywilnym z 7 XII 1944 r. Teki Archiwalne. Seria nowa t. 8(30). Warszawa.

(2011). The Review of some aspects of state sovereignty in the airspace. "The Aviation and Space Journal” No. 1. Università degli Studi di Bologna.

Rosenau, J. (1999). Toward Ontology for Global Governance [in:] Hewson, M., Sinclair, T.J., eds., Approaches to Global Governance Theory. Albany, NY: State University of New York.

Shaw, M.N. (2000). Prawo międzynarodowe. Warszawa.

Stone, D. (2008). Global Public Policy, Transnational Policy Communities and their Networks. "Policy Studies Journal" No. 36(1).

Thaker, J.S. (1997). The development of the outer space benefits declaration. "Annals of Air and Space Law" (AASL), Vol. XXII, section I.

van Fenema, P. (2007). Bilateral air transport agreements - presentation from the Macau conference (16-21 April).

Żylicz, M. (1963). Położenie prawne statku powietrznego w żegludze międzynarodowej. Warszawa (na prawach rękopisu, powielone nakładem PLL LOT).

\section{INTERNET SOURCES}

www.alliance21.org

http://www.unoosa.org/oosa/oosadoc/data/resolutions/1958/general_assembly_13th_session/ res_1348_xiii.html

http://www.unoosa.org/oosa/en/ourwork/un-spider/index.html

http://www.unoosa.org

http://www.unoosa.org/oosa/en/ourwork/copuos/history.html

http://www.un.org/en/charter-united-nations/

http://www.unoosa.org/oosa/oosadoc/data/resolutions/1959/general_assembly_14th_session/ res_1472_xiv.html

https://www.mcgill.ca/iasl/files/iasl/warsaw1929.pdf https://www.un.org/ruleoflaw/files/ 3dd90f0c7.pdf

www.icao.org

www.treaties.un.org 


\section{DOCUMENTS}

ICAO Doc. 7300/8, Annals of Air and Space Law (AASL), Vol. XXX, 2005, Part. I.

A/AC.105/1137, 20 September 2016 Fiftieth anniversary of the United Nations Conference on the Exploration and Peaceful Uses of Outer Space: the Committee on the Peaceful Uses of Outer Space and global governance of outer space activities V.16-05982 (E).

DOI: $10.7862 /$ rz.2019.mmr.12

The text was submitted to the editorial office: February 2019.

The text was accepted for publication: June 2019. 
